\title{
Riittääkö valtavirta opinpaikoiksi - akanvirrat puuttuvat
}

Esko Hartikainen, Päivi Harinen, Leila Hurmalainen (toim.) (2007). OPINPAIKAT. Elämänkulkuja sivistyskansan elämäkerrassa. Kansanvalistusseura.

$\mathrm{H}$ artikaisen, Harisen ja Hurmalaisen toimittamassa teoksen nimen perusteella olemme sivistyskansa. Hyvä niin, vaatimattomuus vain harvoin kaunistaa. Kun sivistystä tarkastellaan yhteiskuntaideologisesta näkökulmasta, on sivistys kansalaiseksi kasvamista ja sivistäminen halutunlaisten suomalaisten muokkaamista (s. 13). Totta tuokin, sivistyneen ihmisen yksi tunnusmerkki on, että hän luissaan ja ytimissään tietää ettei esivalta turhaan miekkaa kanna.

Teoksessa lähestytään yksilöiden opinpaikkoja ja sivistyksen yhteiskuntaideologista ideaa korostuneen voimakkaasti kansakunnan näkökulmasta: miten kansakunta luodaan ja miten kansakuntaa ylläpidetään. Tämä näkyy teoksen rakenteessa, jossa sovelletaan yksilön elämänkaaren vaiheita. Niinpä suomalaisen kansakunnan kehitys on jaettu neljään vaiheeseen. Perimä, syntymä ja lapsuusvaiheeseen, täysi-ikäistymiseen ja -valtaistumiseen, aikuisaikaan sekä kolmanteen ikään ja uusiin alkuihin.

Elämänkaareen palautuva kansakunnan kehityksen vaiheistaminen on kirjoittajien strateginen valinta, joka rakentaa teoksen luettavuuden hyväksi. Samalla ratkaisu merkitsee kuitenkin sitä, että kansakuntamme kehitys tulee kuvatuksi valtavirran kertomuksena, akanvirrat ja joen pienet sivuhaarat häipyvät näkymättömiin. Lukijana minulle syntyi kuva siitä, että teoksen kirjoittajat ovat sivistyneitä ihmisiä. Syvempään opinpaikkojen tarkasteluun, elämäkerran erittelyyn, valitut suomalaiset ovat 'varman päälle valittuja'. Niinpä niin, ehkäpä esivalta ohjasi fouceaulaisittain kirjoittajat "oikeisiin” valintoihin.

Mitäkö tarkoitan opinpaikkojen vaarattomalla valinnalla? Elämäkerralliseen opinpaikkojen erittelyyn on valittu lähinnä turvallisia suomalaisia, joiden nimet tulevat vaiheiden kuvauksen yhteydessä esille. Olisin kaivannut kansakunnan eri kehitysvaiheissa myös valtavirran ulkopuolella olevien ihmisten opinpaikkojen kuvausta ja erittelyä. Pahana puutteena pidän sitä, että sisällissotamme, joka oli Euroopan mittapuussa erittäin raju, ei tule opinpaikkojen yhteydessä kunnolla esiin saati eriteltyä. Kuitenkin juuri se herätti rakentamaan tositoimin suomalaista kansakuntaa; se saatiin rakennettua ja tässä tehtävässä onnistuminen on suomalaisen yhteiskunnan suuri saavutus, jonka rinnalla kaikki muut saavutuksemme kalpenevat.

Kansakunnan perimä, syntymä ja lapsuus käsitellään tunnettujen suomalaisten elämänkertojen kuvauksen ja erittelyn avulla (J.W. Snellman, Uno Cygnaeus, Aleksis Kivi, Minna Canth ja Maria Österberg). On hyvä, että näitä tunnettuja suomalaisia - mukaan lukien Maria Österberg - käsitellään myös sosialisaatioteoreettisesti: miten he ovat kasvaneet aikansa lapsina, miten ponnistelleet itsensä ja yhteisönsä kehittämiseksi ja miten yhteiskunnan rakenteet ovat sittenkin mahdollistaneet heidän pyristelynsä. Tässä jaksossa parasta antia ovat kuitenkin ennen elämäkerran esittelyä kirjoitetut teoreettiset johdannot - tekijöillä on tietoa, näkemystä, kykyä ja kirjoittamisen taitoa.

Täysi-ikäistymisen ja -valtaistumisen vaiheessa esitellään "Tahko" Pihkala, Viktor Bister, Helvi Sipilä, Hiski Salomaa, Väinö Linna sekä Armilan sotalapset. Luvun alaotsikon mukaisesti tässä käsitellään terveen ja ehjän kansakunnan rakentamista - tavoitteena on valkoisen sivistyksen Suomi. Oli ihan kiinnostavaa lueskella näitä elämänkertoja; silti tämä jakso jää kovin kalpeaksi. Ääripäiden olisi pitänyt tulla paremmin näkyviin. Eräs sivistyneistön jo edesmennyt edustaja totesi minulle kahdenkeskisesti, että hänen elämänsä suurin pettymys oli, kun Hitler paljastui retkuksi. Opinpaikkojen ja elämäkertojen erittelyn avulla suomalainen yhteiskunta saisi historiallisessa kertomuksessaan tämän vaietun, mutta todennäköisesti todellisen, piirteensä näkyviin. Myös toista ääripäätä, Neuvostoliittoon loikanneiden noin 20000 suomalaisen opinpaikkoja olisi tullut piirtää esiin.

Kansakunnan aikuisaika -vaiheessa tarkastellaan Eino Poutiaisen, Hectorin, Tommi Hoik- 
kalan sekä vähemmistön edustajana Lahja -nimisen romaninaisen opinpaikkoja. Minkä ajanjakson kansakunnan aikuisaika kattaa? Se ulottuu toisen maailmansodan päättymisestä suureen lamaamme eli 1990-luvun alkuun. Suomessa toteutui tuolloin Euroopan nopein rakennemuutos. Parasta antia tässäkin jaksossa ovat ennen kulloisenkin elämäkerran esittelyä kirjoitetut teoreettiset johdannot. Toisaalta tarkka lukija saa tuosta aikakaudesta paljon tietoa paneutumalla elämäkertoihin, toisaalta niiden ymmärtäminen siten, että mikro- ja makrotaso limittyisivät, vaatii paljon ennakkotietoa.

Lukijana minua suuresti harmittaa tämän aikajakson kuvaus. Suomalaisen kansakunnan aikuisaika peilautui neljään ihmiseen. Keskustan puoluesihteeriin (Poutiainen), vasemmistolaiseen laulajaan (Hector), taistolaiseen opiskelijaliikkeeseen kuuluneeseen sosiologiin (Hoikkala) ja romaniväestön edustajaan. Olisin halunnut lukea lisäksi muutoksen ytimessä toimineiden opinpaikkoja. Ay-liike, teollisuus, kirkko sekä Kekkosen vastustajat loistavat poissaolollaan. Olisivatko Raimo Ilaskivi, Tuure Junnila, Jorma Ollila tai Niilo Hämäläinen, Taisto Sinisalo ja Aarne Saarinen olleet oivallisia opinpaikkojen kuvauksen ja erittelyn kohteina?

Kolmas ikä ja uusia alkuja jakso päättää teoksen. Tässä jaksossa ainoa tunnetumpi esiteltävä suomalainen on Ismo Alanko. Teoksen toimittajat ovat Joensuun yliopistosta ja Joensuun yliopistossa työskenteli aikanaan myös Ismo Alangon äiti. Tämä läheisyysvalinta on tärkeätä nostaa esille, sillä se havainnollistaa kauttaaltaan teoksen keskeisintä pulmaa. Opinpaikkojen erittelyyn, elämäkertojen kuvaukseen valitut ihmiset edustavat luultavasti kirjan keskeisten toimittajien mieltymyksiä. Teoksesta olisi tullut parempi, jos näissä strategisissa valinnoissa olisi oltu kunnianhimoisempia eikä olisi ohjauduttu joko läheisyysperiaatteen, elämäkerran helpon saatavuuden tai 'mikä tuntuu kivalta' -tyyppisistä valintakriteereistä.

Koen tämän kolmannen iän jakson hämmentäväksi. Itäblokin murtuminen ja Berliinin muurin sortuminen merkitsivät yhteiskuntapoliittisen ideologiamme täystuhoa: nelisenkymmentä vuotta Suomea oli rakennettu uskoen siihen, että yhteiskuntakehitystä voidaan ohjata. Tuo ideologia kärsi täydellisen tappion suuressa lamassamme. Suomi joutui pakotetusti - taas kerran - siirtymään uuteen todellisuuteen. On markkinoiden vallan aikakausi. Ja käsi sydämelle suomalaiset. Nykyinen elintasomme on tehokkaiden markkinoiden tuottamaa. Markkinoita on helppo kritisoida, mutta valintatilanteessa ihmiset vaikuttavat valitsevan turbomaasturin luonnonmukaisen ja ekologisen elämän sijasta.

Kolmannen iän jaksossa toteutettu, tulosohjauksen ja markkinoiden kritiikki on jollakin tapaa vanhentunutta. Kun sivistäminen on yhteiskuntaideologisesti halutunlaisten suomalaisten kasvattamista, olisi myös todellisten vallanhaltijoiden opinpaikkojen kuulunut tulla näkyviin. Kenties Björn Wahlroosin elämäkerran erittely opinpaikkojen näkökulmasta olisi puoltanut paikkansa. Supisuomalaisen ja tavallisen pörssipelurin elämäkerta opinpaikkoineen olisi tullut piirtää esiin.
Kenties valtavirran kritiikki olisi löytynyt sieltä parhaiten, missä yhtyvät lahjakkuus, suvaitsevaisuus ja poikkeavuus? Maailmalla arvioidaan kalleimmaksi suomalaiseksi pörssin ulkopuoliseksi yritykseksi Habbohotels, jonka arvo on noin 800 miljoonaa dollaria. Sen perusti 1990-luvun puolivälissä kolme nuorta poikaa, nyt he ovat noin 30-vuotiaita nörttejä. Olisiko heidän opinpaikkansa ollut kuvauksen arvoinen?

Opinpaikat-teos on Kansanvalistusseuran kustantama. Vaikka olenkin arvioinut sitä kriittisesti, arvostan teosta. Se täyttää selvän puutteen. Nykytieteen tiedoin on peilattu suomalaisen yhteiskunnan rakentumista, kehitystä ja henkisiä murroksia. Samalla on kyetty kuvaamaan elämänläheisesti ja inhimillisesti noin kahdenkymmenen ihmisen opinpaikat ja elämäkerrat. Kyllä teos siirtää suomalaista kulttuuriperintöä, siihen hyvin paneutuva lukija oppii paljon eri aikakausien mikrohistoriaa. Teoksen keskeisin puute avautuu kysymällä, mitä se jättää katveeseen? Lukemisen arvoinen teos - suosittelen sitä asiasta kiinnostuneille ja perusopintojen yliopistolliseksi kurssikirjaksi soveltuviin oppiaineisiin.

\section{Juha Varila}

